Conference presentation: L SIR Congress, 2013.

\section{Predictive factors for partial remission according to the Ankylosing Spondylitis Assessment Study working group in patients with ankylosing spondylitis treated with anti-TNF $\alpha$ drugs}

\author{
F.M. Perrotta ${ }^{1}$, O. Addimanda ${ }^{2}$, R. Ramonda ${ }^{3}$, S. D'Angelo ${ }^{4}$, E. Lubrano ${ }^{5}$, \\ A. Marchesoni ${ }^{6}$, I. Olivieri ${ }^{4}$, L. Punzi ${ }^{3}$, C. Salvarani ${ }^{2}$, A. Spadaro ${ }^{1}$ \\ 'UOC di Reumatologia, Dipartimento di Medicina Interna e Specialità Mediche, \\ Università La Sapienza, Roma; \\ 2Unità di Reumatologia, Ospedale di Reggio Emilia, Reggio Emilia; \\ ${ }^{3}$ U.O.C. di Reumatologia, Dipartimento di Medicina DIMED, Università di Padova; \\ ${ }^{4}$ Dipartimento di Reumatologia della Regione Basilicata, Ospedale San Carlo di Potenza \\ ed Ospedale Madonna delle Grazie, Matera; \\ ${ }^{5}$ Dipartimento di Medicina e Scienze per la Salute, Università del Molise, Campobasso; \\ U. O.C. DH Reumatologia, Istituto Ortopedico G. Pini, Milano, Italy
}

The objective of this study was to evaluate the predictive factors for achieving partial remission (PR) in patients with ankylosing spondylitis (AS) treated with anti-TNF $\alpha$. We longitudinally enrolled in a multi-center study 214 AS patients, classified according to New York criteria, treated with anti-TNF $\alpha$ drugs adalimumab (ADA), etanercept (ETA) and infliximab (INF) with at least 12 months of follow up. PR was reached when the score was $<20 \mathrm{~mm}$ (on a visual analogue scale of $0-100 \mathrm{~mm}$ ) in each of the following 4 domains:

1) patient global assessment (in the last week);

2) pain (spinal pain);

3) function [measured by the bath ankylosing spondylitis functional index (BASFI)];

4) inflammation [mean of intensity and duration of morning stiffness, from the bath ankylosing spondylitis disease activity index (BASDAI)].

Two hundred fourteen AS patients $(\mathrm{M} / \mathrm{F}=160 / 54$; median age/range=43.2/19-78 years; median disease duration/range=96/36-189 months) were treated with ADA (15.8\%), ETA (28.9\%) and INF (55.1\%). At 12 and 24 months, high serum level of $\mathrm{C}$ reactive protein (CRP) $(\geq 2 v s \leq 0.8 \mathrm{mg} / \mathrm{dL})$ were associated with higher rate of $\mathrm{PR}$ in AS patients treated with anti-TNF $\alpha$ drugs. At 24 months, PR was associated with shorter disease duration ( $\leq 36 v s \geq 189$ months) and higher erythrosedimentation rate (ESR) values ( $\geq 45 v s \leq 17 \mathrm{~mm} / \mathrm{h}$ ). In male patients lower bath ankylosing spondylitis metrology index (BASMI) $(\leq 2 v s \geq 6)$ and absence of psoriasis were associated with higher PR rate only at 12 months. Other parameters assessed before treatment, such as BASDAI, BASFI, peripheral arthritis, inflammatory bowel disease and uveitis were not associated with PR. Our long-term longitudinal study in a setting of clinical practice showed that inflammatory parameters (i.e. CRP, ESR) and disease duration represent the most important predictive variables to achieve PR with an anti-TNF $\alpha$ treatment.

Key words: Ankylosing spondylitis, Anti-TNF, Remission.
Corresponding author:

Fabio Massimo Perrotta Dipartimento di Medicina Interna

e Specialità Mediche

U.O.C. di Reumatologia Università La Sapienza di Roma

Azienda Policlinico Umberto I Viale del Policlinico, 155 - 00161 Roma, Italy

E-mail: f.perrotta85@gmail.com

\section{INTRODUCTION}

$\mathrm{T}$ umor necrosis factor alpha $(\mathrm{TNF} \alpha)$ antagonists showed their efficacy and safety in controlling disease signs and symptoms of ankylosing spondylitis (AS) (1). The concept of disease remission plays a relevant role in the management of AS, representing a major treatment target that should consider different aspects of the disease, including extra-articular manifestations, i.e. psoriasis, inflammatory bowel disease (IBD), uveitis, and acute phase reactants (2). Owing to the lack of definition of the differentiation between complete clinical remission and a status of 
low disease activity, the Ankylosing Spondylitis Assessment Study (ASAS) working group proposed a score for the definition of partial remission (PR) (3). PR could be reached in $20-40 \%$ of AS patients treated with anti-TNF $\alpha$ drugs, as demonstrated in randomized controlled trials and in clinical practice experiences (4-10). Furthermore, evidence derived from randomized trials and national registries showed that demographic, clinical and laboratory factors, i.e. $\mathrm{C}$ reactive protein (CRP), age, the Bath ankylosing spondylitis functional index (BASFI), enthesitis and HLA-B27, could be predictors of a better clinical response after the introduction of anti-TNF $\alpha$ therapy (11-14). The aim of this study was to evaluate the predictive factors for achieving PR in a large cohort of AS patients treated with adalimumab (ADA), etanercept (ETA) and infliximab (INF) in a real-life clinical setting.

\section{MATERIALS AND METHODS}

A longitudinal observational study was performed in 6 secondary referral rheumatologic Italian centers (Roma, Campobasso, Milano, Padova, Potenza and Reggio Emilia).

We studied 214 AS patients, classified according to New York criteria (15), treated with TNF $\alpha$ antagonist with a follow-up period ranging from 12 to 24 months. ADA (40 mg every two weeks) and ETA (25 mg twice a week or $50 \mathrm{mg}$ once a week) were administered subcutaneously; INF was administered intravenously at $3-5 \mathrm{mg} / \mathrm{kg}$ at 0-2-6 weeks, then every 6-8 weeks. All patients signed an informed consent according to the Declaration of Helsinki and the design of the study was approved by the local ethical committee (La Sapienza University of Rome). At the beginning of the anti$\mathrm{TNF} \alpha$ treatment, the main demographic, clinical, laboratory and radiological characteristics of each AS patients, including gender, age, disease duration, clinical pattern (axial with or without peripheral arthritis), extra-articular manifestations (i.e. psoriasis, IBD, uveitis), HLA-B27 typing and X-ray sacroiliitis grade according to the New York criteria (15) were collected. Bath ankylosing spondylitis metrology index (BASMI) (16), Bath ankylosing spondylitis disease activity index (BASDAI) (17), BASFI (18), the patient's visual analogue scale (VAS) of 0-100 mm on disease activity and overall spinal pain, the number of tender and swollen joints, and laboratory parameters such as erythrosedimentation rate (ESR) and CRP were evaluated at baseline and after 12 and 24 months from anti-TNF $\alpha$ treatment initiation. PR was reached when the score was $<20 \mathrm{~mm}$ (on a VAS of 0-100 mm) in each of the following 4 domains:

1) patient global assessment (in the last week);

2) pain (spinal pain);

3) function (measured by the BASFI); inflammation (mean of intensity and duration of morning stiffness, from the BASDAI) $(2,19)$.

The association of PR with the main variables at baseline was studied. In particular, continuous variables (i.e. age, disease duration, CRP, ESR, BASDAI, BASMI, BASFI) were analyzed by comparing the different quartiles.

All anti-rheumatic treatments, including disease modifying anti-rheumatic drugs (DMARDs), steroids, non-steroidal antiinflammatory drugs (NSAIDs) and comorbidities were recorded. The reasons for discontinuation were classified as lack of efficacy, adverse event, or other reasons. The definition of lack of effectiveness was based on a clinical evaluation according to ASAS/European League Against Rheumatism (EULAR) recommendations for the management of AS (20).

\section{Statistical analysis}

Categorical variables were analyzed using the $\chi$-square test with Yates correction or the Fisher exact test. Association of predictor variables with ASAS partial remission was explored using an odds ratio (OR) with a $95 \%$ confidence interval (CI). OR was interpreted as: 1.5 to 1 weak association; 2.5 to 1 moderate association; 4 to 1 strong association and 10 to 1 very strong 
Table I - Demographic, clinical and laboratory features of ankylosing spondylitis patients $(n=214)$ treated with TNF $\alpha$ blockers at baseline.

\begin{tabular}{|l|l|}
\hline Male (\%) & 74.8 \\
\hline $\begin{array}{l}\text { Median age; years (median/25th-75th } \\
\text { percentile) }\end{array}$ & $43.2 / 34-54$ \\
\hline $\begin{array}{l}\text { Median disease duration; months } \\
\text { (median/25th-75th percentile) }\end{array}$ & $96 / 36-189$ \\
\hline Presence of HLA-B27 (\%) & 62.6 \\
\hline $\begin{array}{l}\text { CRP mg/dL (median/25th-75th } \\
\text { percentile) }\end{array}$ & $1.4 / 0.8-2.8$ \\
\hline $\begin{array}{l}\text { ESR mm/l h (median/25th-75th } \\
\text { percentile) }\end{array}$ & $30 / 17-45$ \\
\hline BASDAI (median/25th-75th percentile) & $5.9 / 4.8-6.5$ \\
\hline BASMI (median/25th-75th percentile) & $3 / 2-4.9$ \\
\hline BASFI (median/25th-75th percentile) & $5.4 / 4.1-6.6$ \\
\hline Presence of grade IV sacroilitis (\%) & 33.1 \\
\hline Presence of peripheral arthritis (\%) & 49.5 \\
\hline Presence of psoriasis (\%) & 11.6 \\
\hline Presence of IBD (\%) & 11.6 \\
\hline Presence of uveitis (\%) & 17.2 \\
\hline $\begin{array}{l}\text { Therapy (\%) } \\
\text { NSAIDs } \\
\text { DMARDs } \\
\text { ADA } \\
\text { ETA } \\
\text { INF }\end{array}$ & 76.1 \\
\hline
\end{tabular}

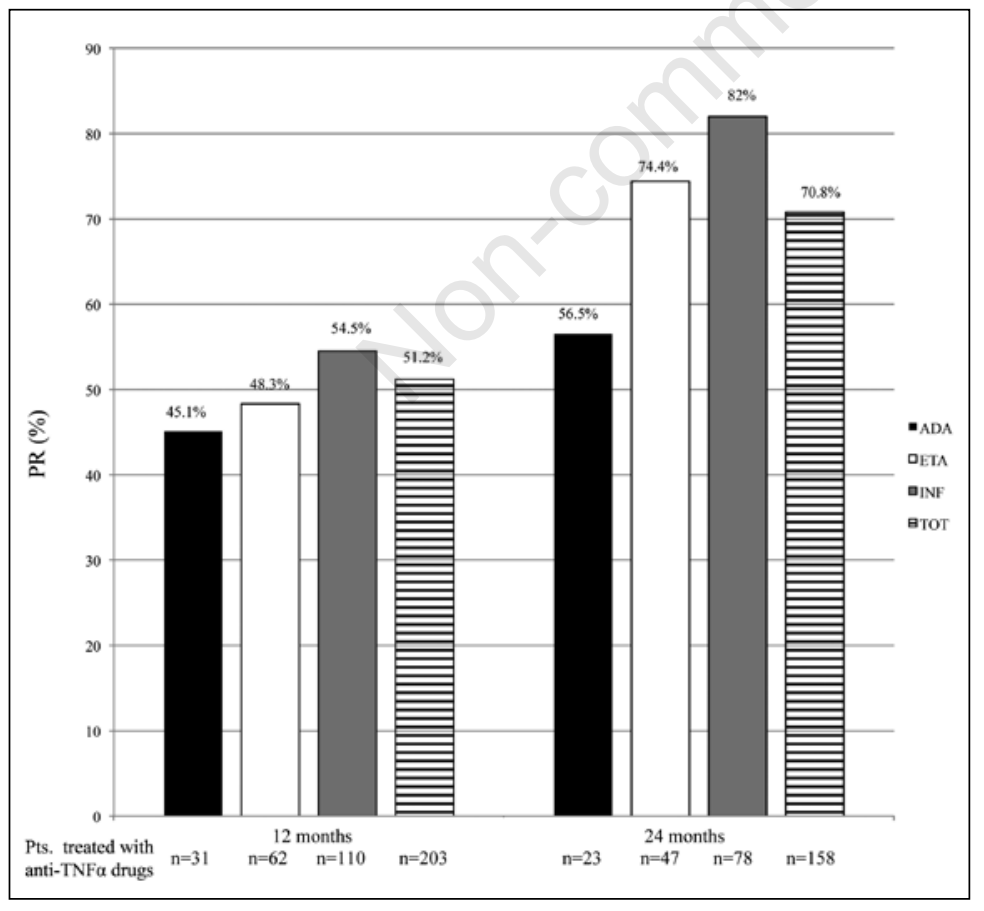

Figure 1 - Partial remission rates in ankylosing spondylitis patients receiving anti-TNF $\alpha$ treatment at $12 \quad(n=203)$ and $24 \quad(n=158)$ months. association. The results were expressed as median $/ 25^{\text {th }}-75^{\text {th }}$ percentile. $P$ values $<0.05$ were considered significant.

\section{RESULTS}

The main demographic, clinical and laboratory features of AS patients $(n=214)$ treated with $\mathrm{TNF} \alpha$ blockers $(\mathrm{ADA}=34, \mathrm{ETA}=62$, $\mathrm{INF}=118$ ) at baseline are shown in Table I. Among the 214 patients, the anti-TNF $\alpha$ treatment was still administered to 203 $(94.8 \%)$ at 12 months and to $158(73.9 \%)$ at 24 months.

During the follow up, the overall rate of discontinuation of anti-TNF $\alpha$ drug was 9.3\% $(\mathrm{n}=20)$, including 11 patients $(5.1 \%)$ who stopped the drug due to loss of effectiveness, $5(2.3 \%)$ patients due to adverse events and $4(1.8 \%)$ for other reasons. ADA, ETA, and INF were discontinued due to loss of effectiveness in 4 (1.8\%), 1 $(0.4 \%)$ and in $6(2.8 \%)$, patients respectively.

PR rates at 12 and 24 months during treatment with ADA, ETA and INF in patients with AS are shown in Figure 1.

The PR rate was not significantly different among all anti-TNF- $\alpha$ (ADA, ETA or INF). During the two-year study, 131 $(61.2 \%)$ patients reached PR. In particular, $113(86.2 \%)$ patients reached PR within 12 months from the beginning of the antiTNF $\alpha$ therapy.

The association of a PR response with the main variables at baseline in AS treated with ADA, ETA and INF at 12 and 24 months of follow up is shown in Table II. In particular, the continuous variables (i.e. age, disease duration, CRP, ESR, BASDAI, BASMI, BASFI) were analyzed by comparing the different quartiles (Table II). At 12 and 24 months, high serum levels of CRP ( $\geq 2 v s \leq 0.8 \mathrm{mg} / \mathrm{dL}$ ), were associated with a higher PR rate in AS patients treated with anti-TNF $\alpha$ drugs. At 24 months, PR was associated with shorter disease duration ( $\leq 36 v s \geq 189$ months) and higher ESR values ( $\geq 45 v s \leq 17 \mathrm{~mm} / \mathrm{h})$. Male sex, lower BASMI $(\leq 2 v s \geq 6)$ and absence of psoriasis were associated with higher PR rate only at 
Table II - Odds ratio (OR) and 95\% confidence intervals $(\mathrm{Cl})$ of partial remission response in ankylosing spondylitis patients treated with ADA, ETA and INF at 12 and 24 months of follow-up.

\begin{tabular}{|c|c|c|c|c|c|}
\hline & & $\begin{array}{l}12 \text { months } \\
\text { Odds ratio } \\
\text { (Cl } 95 \% \text { ) }\end{array}$ & $\mathbf{P}$ & $\begin{array}{l}24 \text { months } \\
\text { Odds ratio } \\
\text { (Cl 95\%) }\end{array}$ & $\mathbf{P}$ \\
\hline Gender & Male vs female & $2.05(1.09-3.84)$ & 0.02 & $1.3(0.60-3.04)$ & n.s. \\
\hline \multirow[t]{3}{*}{ Age (years) } & $\leq 34$ vs $>34-\leq 43$ & $2.01(0.78-5.18)$ & n.s. & $2.16(0.79-5.92)$ & n.s. \\
\hline & $\leq 34$ vs $>43-<54$ & $1.49(0.65-3.40)$ & n.s. & $1.22(0.42-3.50)$ & n.s. \\
\hline & $\leq 34$ vs $\geq 54$ & $2.01(0.90-4.47)$ & n.s. & $2.44(0.94-6.30)$ & n.s. \\
\hline \multirow{3}{*}{$\begin{array}{l}\text { Disease duration } \\
\text { (months) }\end{array}$} & $\leq 36$ vs $>36-\leq 96$ & $0.76(0.34-1.65)$ & n.s. & $1.85(0.58-5.87)$ & n.s. \\
\hline & $\leq 36$ vs $>96-<189$ & $0.81(0.35-1.84)$ & n.s. & $2.08(0.62-6.99)$ & n.s. \\
\hline & $\leq 36$ vs $\geq 189$ & $1.58(0.73-3.41)$ & n.s. & $5(1.59-15.6)$ & 0.005 \\
\hline HLA-B27 & Absence vs presence & $0.86(0.46-1.63)$ & n.s. & $1.31(0.57-2.98)$ & n.s. \\
\hline \multirow[t]{3}{*}{$\mathrm{CRP}(\mathrm{mg} / \mathrm{dL})$} & $\geq 2$ vs $>0.8-\leq 1.5$ & $0.82(0.39-1.70)$ & n.s. & $1.19(0.48-2.93)$ & n.s. \\
\hline & $\geq 2$ vs $>1.5-<2$ & $1.69(0.65-4.42)$ & n.s. & $2.38(0.73-7.83)$ & n.s. \\
\hline & $\geq 2$ vs $\leq 0.8$ & $2.44(1.21-4.93)$ & 0.03 & $3.39(1.43-8.04)$ & 0.005 \\
\hline \multirow[t]{3}{*}{$\mathrm{ESR}(\mathrm{mm} / \mathrm{h})$} & $\geq 45$ vs $>17-\leq 30$ & $1.46(0.66-3.25)$ & n.s. & $1.47(0.49-4.33)$ & n.s. \\
\hline & $\geq 45$ vs $>30-<45$ & $1.96(0.88-4.35)$ & n.s. & $2.38(0.86-2.53)$ & n.s. \\
\hline & $\geq 45$ vs $\leq 17$ & $1.63(0.73-3.62)$ & n.s. & $3.06(1.14-8.15)$ & 0.02 \\
\hline \multirow[t]{3}{*}{ BASDAI } & $\leq 4.8$ vs $>4.8-\leq 5.9$ & $1.25(0.55-2.79)$ & n.s. & $0.8(0.27-2.31)$ & n.s. \\
\hline & $\leq 4.8$ vs $>5.9-<6.5$ & $1.36(0.60-3.06)$ & n.s. & $0.77(0.19-2.56)$ & n.s. \\
\hline & $\leq 4.8$ vs $\geq 6.5$ & $2.08(0.93-4.64)$ & n.s. & $2.17(0.84-5.58)$ & n.s. \\
\hline \multirow[t]{3}{*}{ BASMI } & $\leq 2$ vs $>2-\leq 3$ & $1.65(0.65-3.71)$ & n.s. & $2.3(0.78-4.70)$ & n.s. \\
\hline & $\leq 2$ vs $>3-<6$ & $1.64(0.83-3.21)$ & n.s. & $1.59(0.65-3.24)$ & n.s. \\
\hline & $\leq 2$ vs $\geq 6$ & $3.44(1.28-9.11)$ & 0.01 & $3.06(0.89-10.5)$ & n.s. \\
\hline \multirow[t]{3}{*}{ BASFI } & $\leq 4.5$ vs $>4.5-\leq 5.5$ & $0.84(0.41-1.75)$ & n.s. & $0.48(0.19-1.23)$ & n.s. \\
\hline & $\leq 4.5$ vs $>5.5-<6.5$ & $0.65(0.29-1.44)$ & n.s. & $0.40(0.14-1.09)$ & n.s. \\
\hline & $\leq 4.5$ vs $\geq 6.5$ & $1.32(0.64-2.70)$ & n.s. & $0.88(0.38-2.70)$ & n.s. \\
\hline Sacroiliitis (grade IV) & Absence vs presence & $1.39(0.76-2.56)$ & n.s. & $1.42(0.67-2.97)$ & n.s. \\
\hline Peripheral arthritis & Absence vs presence & $1.47(0.84-1.55)$ & n.s. & $0.63(0.32-1.25)$ & n.s. \\
\hline Psoriasis & Absence vs presence & $2.46(0.98-6.16)$ & 0.05 & $2.18(0.79-6)$ & n.s. \\
\hline IBD & Absence vs presence & $0.7(0.29-1.71)$ & n.s. & $0.75(0.25-2.23)$ & n.s. \\
\hline Uveitis & Absence vs presence & $1.45(0.7-2.46)$ & n.s. & $1.95(0.82-4.58)$ & n.s. \\
\hline
\end{tabular}

12 months. Other parameters assessed before treatment, such as BASDAI, BASFI, peripheral arthritis, IBD and uveitis, were not associated with PR.

\section{DISCUSSION}

A state of remission or inactive disease is the main objective in chronic inflammatory conditions such as AS (4). Several studies showed that the widespread use of anti-
$\mathrm{TNF} \alpha$ drugs could induce a state of clinical remission in about $20-40 \%$ of AS patients. In our observational study, in a setting of clinical practice, we confirmed high rate of PR in AS patients who started anti-TNF $\alpha$ treatment with ADA, ETA and INF. In particular, PR was achieved in 50.4\% and $48.6 \%$ of AS patients treated with antiTNF $\alpha$ after 12 and 24 months of follow up, respectively. The PR rate with ADA, ETA or INF was not significantly different among all anti-TNF $\alpha$ patients. 
Our experience in a clinical practice setting, confirmed previous results that high serum level of CRP were associated with a higher rate of $\mathrm{PR}$ in AS patients treated with anti-TNF $\alpha$ drugs (14). In fact, ASSERT and GO-RAISE trial data were analyzed to identify baseline predictors for various disease-state and disease-activity outcome instruments in AS (14). In this study CRP, together with age, BASFI score, enthesitis, therapy and HLA-B27 genotype, was identified as a predictor variable with selected outcome instruments, including ASAS PR at six months (14). These results are in keeping with other studies showing that CRP was associated to BASDAI 50 response $(12,21)$.

Moreover, in our study the evidence that high ESR $(\geq 45 \mathrm{~mm} / \mathrm{h})$ had a predictive value supports that this inflammation parameter could be considered an alternative in cases where CRP is not available, according to the use of AS disease activity score (ASDAS) with CRP or ESR (22). The strong association of short disease duration ( $\leq 36$ months) with PR confirmed the results of Rudwaleit et al., who analyzed factors associated to clinical response BASDAI 50 in two clinical trials on ETA and INF (21).

This association could be an important issue in order to suggest an early treatment intervention. Furthermore, in our study we found that patients with lower BASMI $(\leq 2)$ before starting an anti-TNF $\alpha$ therapy had a higher PR rate compared with patients with higher BASMI score $(\geq 6)$. This metrology parameter, even in the absence of inflammatory activity, could influence the domains of PR, such as BASFI and the patient global assessment, reducing the probability of achieving a remission status. In our study, the presence of grade IV sacroiliitis did not affect the PR rate. These results suggest that the TNF $\alpha$ treatment could be useful also in patients with severe axial involvement according to the efficacy of ADA in AS patients with a total spine ankylosis (23). Female sex is considered a risk factor for functional disability, but its predictive value for clinical response to anti-TNF $\alpha$ in AS has not been reported (24). In our study a weak evidence of association of male gender with PR was demonstrated only at 12 months. In our study, other baseline variables (i.e. age, HLA-B27, BASDAI, BASFI and peripheral involvement) did not affect the $\mathrm{PR}$ rate. The weak association of BASDAI with PR could be due to the inclusion criteria giving a homogeneous selection of patients based on elevated BASDAI scores. Among extra-articular manifestations, the predictive value of psoriasis with a good clinical response to antiTNF $\alpha$ drugs is still debated $(5,24,25)$. In our experience, the presence of psoriasis at baseline evaluation was associated with a lower PR rate after 12 months of antiTNF $\alpha$ therapy.

Some discrepancies of our results with previous studies can be explained by a different definition of cut-off levels of putative predictive variables, different outcome measures, study designs and follow-up periods.

In particular, it has to be emphasized that observational studies might yield different findings from those coming from randomized controlled trials.

A limitation of this study was the lack of magnetic resonance imaging (MRI) of sacroiliac joints and spine, but in our experience, based on clinical practice, the availability of MRI was not mandatory for recruitment.

MRI is actually the cornerstone of the classification of non-radiographic axial spondyloartritis and some studies showed the ability of anti-TNF $\alpha$ to reduce the presence and extension of the inflammatory lesion on MRI. Furthermore, other experience demonstrated the predictive value of bone marrow edema to achieve clinical response to anti-TNF $\alpha$ both in patients with SA and non-radiographic axial spondyloarthritis $(26,27)$.

In conclusion, our long-term study in a setting of clinical practice showed that inflammatory parameters (i.e. CRP, ESR) and disease duration represent important predictive variables to achieve PR with anti-TNF $\alpha$ treatment, irrespective of damage or sacroiliac joint involvement. 


\section{REFERENCES}

1. Braun J, van den Berg R, Baraliakos X, Boehm $\mathrm{H}$, Burgos-Vargas R, Collantes-Estevez E, et al. 2010 update of the ASAS/EULAR recommendations for the management of ankylosing spondylitis. Ann Rheum Dis. 2011; 70: 896904.

2. Smolen JS, Braun J, Dougados M, Emery P, Fitzgerald O, Helliwell P, et al. Treating spondyloarthritis, including ankylosing spondylitis and psoriatic arthritis, to target: recommendations of an international task force. Ann Rheum Dis. 2014; 73: 6-16.

3. Anderson JJ, Baron G, van der Heijde D, Felson DT, Dougados M. Ankylosing spondylitis assessment group preliminary definition of short-term improvement in ankylosing spondylitis. Arthritis Rheum. 2001; 44: 1876-86.

4. Zochling J, Braun J. Remission in ankylosing spondylitis. Clin Exp Rheumatol 2006; 24: S88-92.

5. Spadaro A, Lubrano E, Marchesoni A, D'Angelo S, Ramonda R, Addimanda $\mathrm{O}$, et al. Remission in ankylosing spondylitis treated with anti-TNF- $\alpha$ drugs: a national multicentre study. Rheumatology (Oxford). 2013; 52: 1914-9.

6. Braun J, Brandt J, Listing J, Zink A, Alten R, Golder W, et al. Treatment of active ankylosing spondylitis with infliximab: a double-blind placebo controlled multicentre trial. Lancet. 2002; 359: 1187-93.

7. Braun J, Brandt J, Listing J, Zink A, Alten R, Burmester $\mathrm{G}$, et al. Long term efficacy and safety of infliximab in the treatment of ankylosing spondylitis. An open, observational, extension study of a three-month, randomized, placebo-controlled trial. Arthritis Rheum. 2003; 48: 2224-33.

8. van der Heijde D, Dijkmans B, Geusens P, Sieper J, DeWoody K, Williamson P, et al. Efficacy and safety of infliximab in patients with ankylosing spondylitis. Results of a randomized, placebo-controlled trial (ASSERT). Arthritis Rheum. 2005; 52: 582-91.

9. Inman RD, Davis JC Jr, Heijde Dv, Diekman L, Sieper J, Kim SI, et al. Efficacy and safety of golimumab in patients with ankylosing spondylitis: results of a randomized, doubleblind, placebo-controlled, phase III trial. Arthritis Rheum. 2008; 58: 3402-12.

10. Landewé R, Braun J, Deodhar A, Dougados M, Maksymowych WP, Mease PJ, et al. Efficacy of certolizumab pegol on signs and symptoms of axial spondyloarthritis including ankylosing spondylitis: 24-week results of a double-blind randomised placebo-controlled Phase 3 study. Ann Rheum Dis. 2014; 73: 39-47.

11. Lord PA, Farragher TM, Lunt M, Watson KD, Symmons DP, Hyrich KL, et al. BSR Biologics Register. Predictors of response to anti-
TNF therapy in ankylosing spondylitis: results from the British Society for Rheumatology Biologics Register. Rheumatology (Oxford). 2010; 49: 563-70.

12. de Vries MK, van Eijk IC, van der Horst-Bruinsma IE, Peters MJ, Nurmohamed MT, Dijkmans BA, et al. Erythrocyte sedimentation rate, C-reactive protein level, and serum amyloid a protein for patient selection and monitoring of anti-tumor necrosis factor treatment in ankylosing spondylitis. Arthritis Rheum. 2009; 61: 1484-90.

13. Glintborg B, Ostergaard M, Krogh NS, Dreyer L, Kristensen HL, Hetland ML. Predictors of treatment response and drug continuation in 842 patients with ankylosing spondylitis treated with anti-tumour necrosis factor: results from 8 years' surveillance in the Danish nationwide DANBIO registry. Ann Rheum Dis. 2010; 69: 2002-8.

14. Vastesaeger $\mathrm{N}$, van der Heijde $\mathrm{D}$, Inman RD, Wang Y, Deodhar A, et al. Predicting the outcome of ankylosing spondylitis therapy. Ann Rheum Dis. 2011; 70: 973-81.

15. van der Linden S, Valkenburg HA, Cats A. Evaluation of diagnostic criteria for ankylosing spondylitis. A proposal for modification of the New York criteria. Arthritis Rheum. 1984; 27: 361-8

16. Jenkinson TR, Mallorie PA, Whitelock HC, Kennedy LG, Garrett SL, Calin A. Defining spinal mobility in ankylosing spondylitis (AS). The bath AS metrology index. J Rheumatol. 1994; 21: 1694-8.

17. Garret S, Jenkinson T, Kennedy LG, Whitelock H, Gaisford P, Calin A. A new approach to defining disease status in ankylosing spondylitis: the bath ankylosing spondylitis disease activity index. J Rheumatol. 1994; 21: 228691.

18. Calin A, Garrett S, Whitelock H, Kennedy LG, O'Hea J, Mallorie P, et al. A new approach to defining functional ability in ankylosing spondylitis: the development of the bath ankylosing spondylitis functional index. J Rheumatol. 1994; 21: 2281-5.

19. Brandt J, Listing J, Sieper J, Rudwaleit M, van der Heijde D, Braun J. Development and preselection of criteria for short term improvement after anti- TNF alpha treatment in ankylosing spondylitis. Ann Rheum Dis. 2004; 63: 1438-44.

20. Zochling J, van der Heijde D, Burgos-Vargas R, Collantes E, Davis JC Jr, Dijkmans B, et al. ASAS/EULAR recommendations for the management of ankylosing spondylitis Ann Rheum Dis. 2006; 65: 442-52.

21. Rudwaleit M, Listing J, Brandt J, Braun J, Sieper J. Prediction of a major clinical response (BASDAI 50) to tumour necrosis factor alpha blockers in ankylosing spondylitis. Ann Rheum Dis. 2004; 63: 665-70. 
22. van der Heijde, Lie E, Kvien TK, Sieper J, Van den Bosch F, Listing J, et al. ASDAS, a highly discriminatory ASAS-endorsed disease activity score in patients with ankylosing spondylitis. Ann Rheum Dis. 2009; 68: 1811-18.

23. van der Heijde D, Pangan AL, Schiff MH, Braun J, Borofsky M, Torre J, et al. Adalimumab effectively reduces the signs and symptoms of active ankylosing spondylitis in patients with total spinal ankylosis. Ann Rheum Dis. 2008; 67: 1218-21.

24. Rudwaleit M, Claudepierre P, Wordsworth P, Cortina EL, Sieper J, Kron M, et al. Effectiveness, safety, and predictors of good clinical response in 1250 patients treated with adalimumab for active ankylosing spondylitis. J Rheumatol. 2009; 36: 801-8.
25. Braun J, Rudwaleit M, Kary S, Kron M, Wong RL, Kupper H. Clinical manifestations and responsiveness to adalimumab are similar in patients with ankylosing spondylitis with and without concomitant psoriasis. Rheumatology (Oxford). 2010; 49: 1578-89.

26. van der Heijde D, Maksymowych WP, Sieper J, Lambert R, Brown MA, Rathmann SS, et al. Relationship between MRI and clinical remission in patients with non-radiographic axial spondyloarthritis after two years of adalimumab therapy. Arthitis Rheum. 2013; 65: 1801. [abstract]

27. Rudwaleit M, Schwarzlose S, Hilgert ES, Listing J, Braun J, Sieper J. MRI predicting a major clinical response to anti-tumor necrosis factor treatment in ankylosing spondylitis. Ann Rheum Dis. 2008; 67: 1276-81. 